\title{
Comparative microbiological analysis of raw fishes and sun-dried fishes collected from the Kawran bazaar in Dhaka city, Bangladesh
}

\author{
${ }^{1}$ Nur, I.T., ${ }^{1}$ Ghosh, B.K. and ${ }^{2, *}$ Acharjee, M. \\ ${ }^{1}$ Department of Microbiology, Stamford University Bangladesh, 51 Siddeswari Road, Dhaka-1217, \\ Bangladesh \\ ${ }^{2}$ Department of Molecular and Developmental Biology, Graduate School of Science and Technology, \\ Shizuoka University, Oya 836, Suruga-ku, Shizuoka, 422-8529, Japan
}

\begin{abstract}
Article history:
Received: 7 November 2019

Received in revised form: 25

November 2019

Accepted: 28 November

2019

Available Online: 2 February 2020
\end{abstract}

\section{Keywords:}

Raw fishes,

Dry fishes,

Pathogen,

Microbiological Quality

\section{DOI:}

https://doi.org/10.26656/fr.2017.4(3).368

\begin{abstract}
Along with the raw fishes, dry fishes also have a huge contribution to meet up the demand of protein in our daily meal. The assay of microbiological quality is therefore needed to ensure the public health safety. The present study was emphasized on the existence of pathogenic bacteria in raw and dry fish. A total of 50 samples of raw fishes and sun-dried fishes was accumulated aseptically for microbiological quality analysis. Isolation of bacteria was done by spread plate method. All the samples including both (raw and dry) fishes harbored bacteria and fungi up to $10^{6} \mathrm{CFU} / \mathrm{g}$. E. coli was found in all samples as a specific pathogen. In case of raw fishes total viable count (TVC) and total coliform count (E. coli) were recorded up to $2.5 \times 10^{6} \mathrm{CFU} / \mathrm{g}$ and $5.2 \times 10^{4} \mathrm{CFU} / \mathrm{g}$ respectively whereas a significant load of Salmonella spp. was observed in almost all samples. Staphylococcus spp. and Pseudomonas spp. were present up to $5 \times 10^{2} \mathrm{CFU} / \mathrm{g}$ and $1.8 \times 10^{2} \mathrm{CFU} / \mathrm{g}$ respectively. Likewise, total viable count (TVC), total coliform count (E. coli) and fungal load were recorded in dry fish up $3.50 \times 10^{5} \mathrm{CFU} / \mathrm{g}, 1.2 \times 10^{3} \mathrm{CFU} / \mathrm{g}$ respectively. Fungal growth was observed in all experimental raw and dried fishes. For most of the pathogenic isolates, higher rates of resistance were found against Ceftriaxone, Penicillin, Nalidixic acid, Neomycin. On the other hand, most of the isolates were found to retain higher sensitivity against Imipenem, Ciprofloxacin, Tetracyclin and Amoxicillin. This data suggested that the dry fish harbored fewer bacteria than raw fish and sun drying method is still a useful technique for the preservation of fish.
\end{abstract}

\section{Introduction}

Fishes play an important role in human diets as good sources of animal protein that also provide other important elements necessary for the maintenance of healthy bodies (Dewi et al, 2011; Ravichandran et al., 2012). Because of its high nutritive value, sea fishes are a major vehicle for pathogenic microorganisms (Das et al., 2007; Geetha et al., 2014). Fishes begin hostile by both the aquatic environment and post-harvesting condition (Al-Sheraa et al., 2018). Due to the attack of pathogenic bacteria and fungi a wide range of fish spoilage occurs which adversely affect the economic condition in Bangladesh and as well as the public health safety (Khan and Khan, 2001; Musa et al., 2010; Dewi et al., 2011). Consumption of improperly cooked fish may sometimes cause fish-bearing intoxication, which is due to continual subjection of the fish to the microbes present in the water or during transportation (Shabeeb et al., 2016).
Several methods have been implementing over the year in the world for preserving fish to extend its shelf life including drying, salting and smoking. Sun drying of fishes is an efficacious and formerly known method of fish preservation. In tropical countries like Bangladesh, fish drying is a prime and inexpensive preservation method (Balachandran, 2001). Dried fish known as 'Shutki' in Bangladesh is one of the popular food items to the various consumers in the globe due to its high protein content and other essential nutrients as well (Arannilewa et al., 2006). In Bangladesh point of view, the fish drying process is widely performed by the community of the coastal region (Balachandran, 2001). Fish drying process preserves the quality for a prolonged time and offers a unique taste, flavored and minimum deterioration in the product. Traditional drying methods cannot be applied during the monsoon because of the high humidity. By this time, the fish can absorb the moisture and microbial population such as bacteria, fungi and even viruses (Chowdhury and Bagluis, 1997; Khan 
and Khan 2001; Azam, 2002). Fungal contamination is a common problem and adversely affects the quality of fishes. The presence of different types of fungi in dried fishes has been reported earlier (FAO 1982; Gupta and Samuvel 1985; Atapattu and Sararajeewa, 1990; Prakash, 2011; Shanthini and Patterson, 2012).

However, the main principle of fish drying is to stop the progress of muscle enzymatic activity and microbial growth by reducing the water activity of fish. Other problems markedly evident with dried fish are the indiscriminate use of various types of pesticides (Nowsad, 2005). In some of the cases, due to the chemical agent histamine, the food borne illness such as scombroid poisoning is observed in dry fishes (Patterson and Ranjitha, 2009). In sun-dried fishes, E. coli is responsible for the production of histamine. Infrequently, Salmonella and Staphylococcus species also produce histamine residue (Kim et al., 2003). Currently, the demand of drying fish is decreasing in the market due to the anomaly at different stages of dry fish processing including low-quality raw fish for drying, traditional drying practices, unhygienic and improper sanitation facilities and random use of unaccredited chemicals and insecticides (Yam et al., 2015; Hasan et al., 2016). A few works have been done on the quality assessment of dried fish in our country. Considering all these facts, the present study was designated to determine and compare the microbiological quality and the drug resistant feature of the bacterial species among raw fishes and sun-dried fishes.

\section{Materials and methods}

\subsection{Study area and sample collection}

The experiment was executed with a total 50 samples on both raw fish (five samples of each raw fish type, $n=25$ ) and dry fish (five samples of each dry fish type, $\mathrm{n}=25$ ) of the same species including Rupchada (Pomfret; Brama brama), Lote (Bombay duck; Harpadon neherreus), Chingri (Prawn; Penaeus monodon), Puti (Swamp barb; Puntius chola), Mola carplet (Amblyphryngodon microlepi). The samples were collected from Kawran bazar in Dhaka city using a sterile aseptic container together with ice for raw fishes. A total of $20 \mathrm{~g}$ of each the raw and dried of each fish was homogenized with $180 \mathrm{~g}$ of sterile normal saline. The homogenized suspension was subjected to serial dilutions (10-fold) up to $10^{-4}$ with normal saline (Nur et al., 2020).

\subsection{Enumeration of total viable bacteria and fungus}

A total of $0.1 \mathrm{~mL}$ of each sample was spread onto nutrient agar and Sabouraud dextrose agar (SDA) for enumerating total viable bacteria (TVB) and total fungal respectively. For TVB, plates were incubated at $37^{\circ} \mathrm{C}$. For fungal assay, plates were incubated at $25^{\circ} \mathrm{C}$ for 3 days (Acharjee et al., 2014).

\subsection{Isolation of total coliform and fecal coliform}

For enumeration of coliforms and fecal coliforms MacConkey agar and membrane fecal coliform agar $(\mathrm{mFC})$ are used respectively. A total of $0.1 \mathrm{~mL}$ suspension was spread over MacConkey agar and $\mathrm{mFC}$ agar. For the isolation of Escherichia coli and Klebsiella spp., plates were incubated at $37^{\circ} \mathrm{C}$ for $18-24 \mathrm{hrs}$. Presence of $E$. coli was further confirmed by the appearance of bluish-black colonies with green metallic sheen on eosin-methylene blue (EMB) agar (Acharjee et al., 2014). On the other hand, while for fecal coliforms, plates were incubated at $44.5^{\circ} \mathrm{C}$ for $24 \mathrm{hrs}$.

\subsection{Isolation of other pathogenic bacteria}

From each of the $10^{-3}$ dilution, $0.1 \mathrm{~mL}$ of suspension had was spread onto Xylose Lysine Deoxycholate (XLD) for the isolation of Shigella spp. and Salmonella spp. and Thiosulphate Citrate Bile Salt Sucrose (TCBS) agar plates for detecting the presence of Vibrio spp. For the isolation of Pseudomonas spp. and Staphylococcus spp., $0.1 \mathrm{~mL}$ from dilution $10^{-3}$ of the sample was spread on cetrimide agar and MSA agar respectively. After the incubation at $37^{\circ} \mathrm{C}$ for $24 \mathrm{hrs}$, characteristic colonies were observed. (Cappuccino and Sherman, 1996). Finally, a series of biochemical tests were performed following the standard methods to confirm the pathogenic identification (Cappuccino and Sherman, 1996) (Table 1).

\subsection{Determination of antimicrobial susceptibility}

All the isolates were tested to observe their antibiotic susceptibility pattern against the 10 antibacterial drugs (including first, second and third-generation drugs) by disc diffusion assay on Mueller-Hinton Agar (Difco, Detroit, MI) with antibiotic discs (Neo-Sensitabs, Rosco, Denmark) according to the modified Kirby-Bauer method (Bauer et al., 1966; Ferraro et al., 2001; Munshi et al., 2012). A single colony of each isolate was inoculated into $2 \mathrm{~mL}$ of Mueller-Hinton broth and incubated at $37^{\circ} \mathrm{C}$ for $4 \mathrm{hrs}$. The culture turbidity was then adjusted to a $0.5 \mathrm{McF}$ arland standard. Sterile cotton swabs were dipped into the suspensions and spread evenly over the entire surface of Muller-Hinton agar. Antibiotic discs of appropriate concentrations (Neomycin $10 \mu \mathrm{g}$, Chloramphenicol $10 \mu \mathrm{g}$, Polymyxin B $30 \mu \mathrm{g}$, ofloxacin $5 \mu \mathrm{g}$, amoxicillin $10 \mu \mathrm{g}$, ciprofloxacin 5 $\mu \mathrm{g}$, cefpodoxime $30 \mu \mathrm{g}$, nalidixic acid $30 \mu \mathrm{g}$, imipenem $10 \mu \mathrm{g}$, tetracycline $30 \mu \mathrm{g}$,) were placed aseptically over 
Table 1. Biochemical tests of different pathogens

\begin{tabular}{|c|c|c|c|c|c|c|c|c|c|c|c|}
\hline \multirow[b]{2}{*}{$\begin{array}{c}\text { Pathogenic } \\
\text { microorganisms }\end{array}$} & \multicolumn{4}{|c|}{ TSI } & \multirow[b]{2}{*}{$\begin{array}{l}\text { Z } \\
\stackrel{0}{E} \\
\stackrel{\Xi}{\rightleftarrows}\end{array}$} & \multirow{2}{*}{ 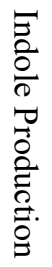 } & \multirow[b]{2}{*}{ 及 } & \multirow[b]{2}{*}{$\lesssim$} & \multirow{2}{*}{ 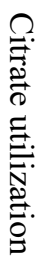 } & \multirow[b]{2}{*}{ 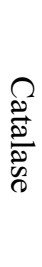 } & \multirow[b]{2}{*}{ 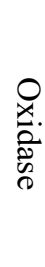 } \\
\hline & $\stackrel{\mathscr{Q}}{\stackrel{2}{\overparen{D}}}$ & $\stackrel{\varpi}{\Xi}$ & $\begin{array}{l}\Omega \\
\text { D. }\end{array}$ & $\underset{\sim}{\mathbb{T}}$ & & & & & & & \\
\hline E. coli & $\mathrm{Y}$ & $\mathrm{Y}$ & + & - & + & + & + & - & - & + & - \\
\hline Shigella spp. & $\mathrm{R}$ & $\mathrm{Y}$ & - & - & $+/-$ & + & - & - & - & - & - \\
\hline Klebsiella spp. & $\mathrm{Y}$ & $\mathrm{Y}$ & + & - & + & - & - & - & + & + & - \\
\hline Vibrio spp. & $\mathrm{R}$ & Y & - & - & + & - & + & - & - & + & + \\
\hline Staphylococcus spp. & $\mathrm{Y}$ & $\mathrm{Y}$ & - & - & + & - & + & - & - & + & - \\
\hline Pseudomonas spp. & $\mathrm{R}$ & Y & - & - & + & - & + & - & - & + & + \\
\hline Salmonella spp. & $\mathrm{R}$ & $\mathrm{Y}$ & - & + & + & - & + & - & - & + & - \\
\hline
\end{tabular}

All the experiments have been done three times and the results were reproducible. One representative data have been shown. TSI: Triple Sugar Iron Test, Y: Yellow (Acid), R: Red (Alkaline), MR: Methyl red, VP: Voges-Proskauer

the surface at appropriate spatial distance of $5 \mathrm{~mm}$. Plates were then inverted and incubated at $37^{\circ} \mathrm{C}$. After 24 hours, plates were examined and the diameters of the zones of inhibition were measured and interpreted as susceptible, intermediate and resistant.

\section{Results and discussion}

Fish is extremely susceptible to microbial contamination because of their soft tissues and the aquatic environment. Millions of bacteria are present in the surface of slime, on the gills and in the intestines of live fish. Many of them become potential spoilers after the death of fish when the defense system breaks down and the bacteria multiply and invade the flesh. One of the major factors contributing to poor quality of the fish in retail trade is unhygienic handling, improper storage, physical damage and come to contact in dirty water and microorganisms. Bacterial spoilage is characterized by softening of the muscle tissue and the production of slime and offensive odors. Data is represented in Figure 1.

The highest total viable bacterial (TVB) load was observed in raw Penaeus monodon which is $2.5 \times 10^{6}$ $\mathrm{CFU} / \mathrm{g}$ where among the raw fishes the lowest count of TVB was recorded in Brama brama which is $2.7 \times 10^{5}$ $\mathrm{CFU} / \mathrm{g}$. However, all dried fish samples exhibit comparatively lower bacterial load than that of their corresponding raw fishes. Fungal growth was observed in all experimental raw and dried fishes. Highest fungal load was observed in raw Penaeus monodon whereas surprisingly fungal load was nill in case of dry Penaeus monodon. Total fecal coliform was absent in all samples whereas Escherichia coli was present in all samples which reflects the previous study of Saritha et al. (2012). In case of raw Harpadon nehereus a higher load of $E$. coli was reported $\left(5.2 \times 10^{4} \mathrm{CFU} / \mathrm{g}\right)$ and lowest count of E. coli was recorded in Brama brama and that was $2.51 \times 10^{3} \mathrm{CFU} / \mathrm{g}$. Klebsiella spp. was present in raw and dry Penaeus monodon, raw and dry Puntius chola and raw Amblypharyn godonmicrolepis and their count was recorded $6.2 \times 10^{3} \mathrm{CFU} / \mathrm{g}, 1.5 \times 10^{2} \mathrm{CFU} / \mathrm{g}, 2.51 \times 10^{2} \mathrm{CFU} /$ g, $2.6 \times 10^{4} \mathrm{CFU} / \mathrm{g}$ and $2.2 \times 10^{3} \mathrm{CFU} / \mathrm{g}$ respectively. Staphylococcus spp. was present in Dry Penaeus monodon, raw and dry Brama brama and raw Abmblypharyn godonmicrolepis. Shigella spp. was only found in raw Brama brama and the count is $5.6 \times 10^{3}$ CFU/g. A significant load of Salmonella spp. was observed in almost all samples. Salmonella spp. was found in raw Penaeus monodon, raw Harpadon nehereus, raw Brama brama, raw and dry Puntius chola and the count was $2.5 \times 10^{2} \mathrm{CFU} / \mathrm{g}, 4.6 \times 10^{2} \mathrm{CFU} / \mathrm{g}$, $2.7 \times 10^{2} \mathrm{CFU} / \mathrm{g}, \quad 3.5 \times 10^{3} \mathrm{CFU} / \mathrm{g}, \quad 6.5 \times 10^{2} \mathrm{CFU} / \mathrm{g}$ respectively. Pseudomonas spp. was present in all raw samples and two dry samples did not exhibit the presence of Pseudomonas spp. Vibrio spp. recorded in raw Harpadon nehereus, raw and dry Brama brama, raw Puntius chola.

For most of the pathogenic isolates, higher rates of resistance were found against imipenem (10 $\mu \mathrm{g})$, ciprofloxacin (5 $\mu \mathrm{g})$, ceftriaxone $(30 \mu \mathrm{g})$, chloramphenicol (10 $\mu \mathrm{g})$, nalidixic acid $(30 \mu \mathrm{g})$, Neomycin (Table 2). On the other hand, most of the isolates were found to retain higher sensitivity against Tetracyclin and Amoxicillin.

In the present study, bacterial and fungal colonies were observed in the commercial sun-dried sea fishes. This may be due to post-harvest delay, improper transportation, unhygienic handling and processing during the salting and sun-drying process, contaminated working floor, salt and water. The fungal species such as Aspergillus sp., Mucor sp., Rhizopus sp. and Fusarium sp. are pathogenic to the human beings (Sharma, 1989; Felicia and Jamila, 2003) and reported to cause food spoilage. Vibrio spp. is a halophilic bacterium usually present in the marine environment but in the case of Salmonella spp., it does not occur naturally in marine 


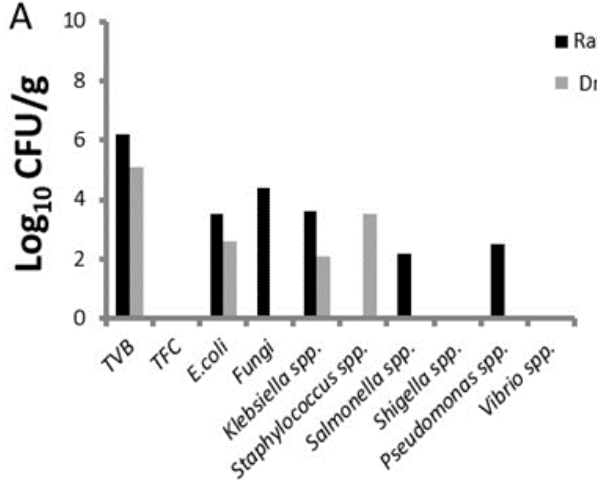

Bacteria
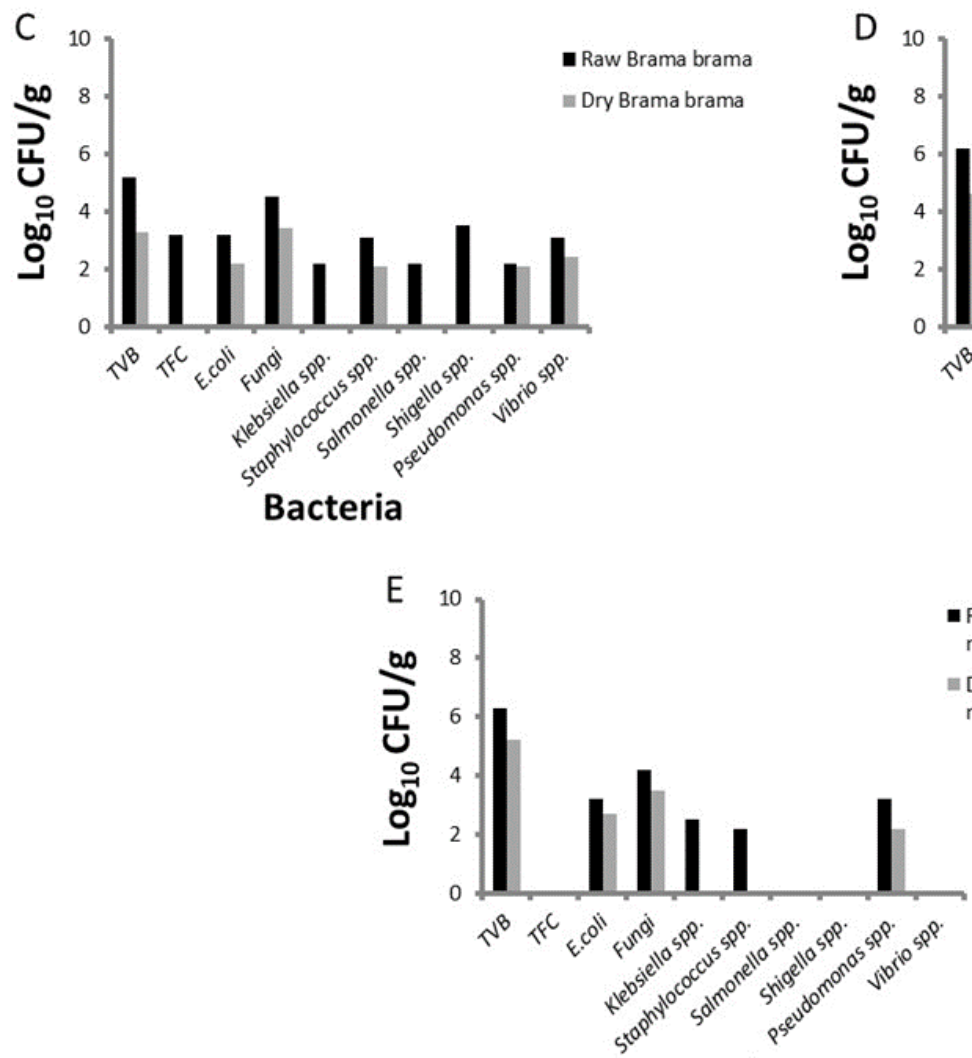

Bacteria
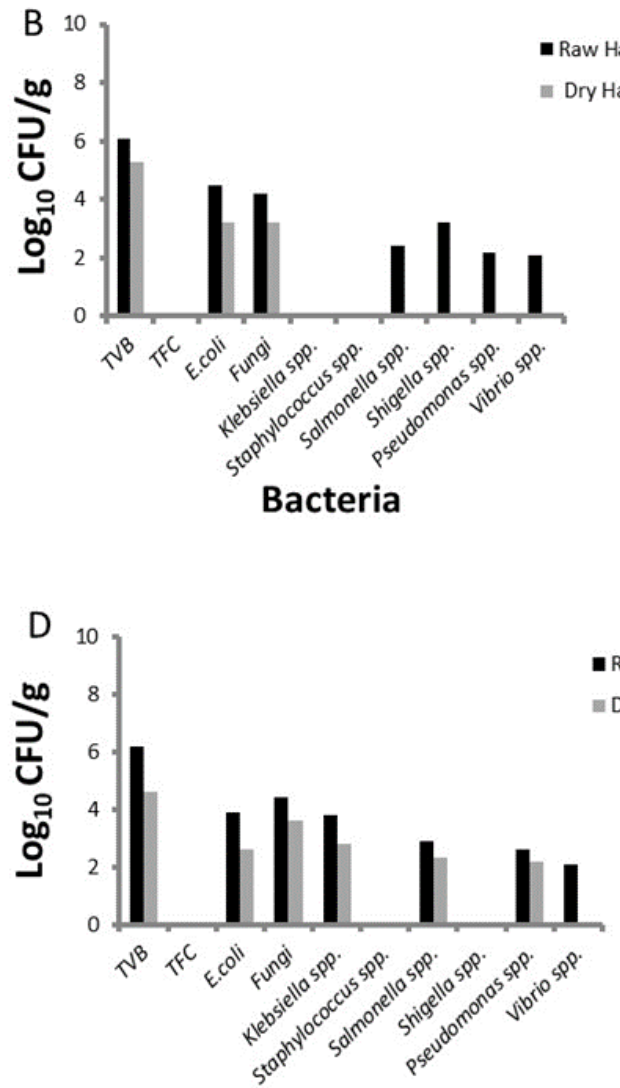

Bacteria

Raw Amblypharyngodon microlepis

Dry Amblypharyngodon microlepis

Raw Harpadon nehereus

Dry Harpadon nehereus Dry Puntius Chola

Figure 1. Comparative microbiological analysis of raw fishes and dry fishes

Table 2. Antimicrobial susceptibility pattern of different pathogenic isolates isolated from the dry and raw fish samples

\begin{tabular}{|c|c|c|c|c|c|c|c|c|c|c|c|c|c|c|}
\hline \multirow{2}{*}{$\frac{\text { Organisms }}{\text { Antibiotics }}$} & \multicolumn{2}{|c|}{ E. coli } & \multicolumn{2}{|c|}{ Klebsiella spp. } & \multicolumn{2}{|c|}{ Shigella spp. } & \multicolumn{2}{|c|}{ Salmonella spp. } & \multicolumn{2}{|c|}{$\begin{array}{l}\text { Pseudomonas } \\
\text { spp. }\end{array}$} & \multicolumn{2}{|c|}{$\begin{array}{c}\text { Staphylococcus } \\
\text { spp. }\end{array}$} & \multicolumn{2}{|c|}{ Vibrio spp. } \\
\hline & $\mathrm{R}$ & $\mathrm{S}$ & $\mathrm{R}$ & $\mathrm{S}$ & $\mathrm{R}$ & $\mathrm{S}$ & $\mathrm{R}$ & $\mathrm{S}$ & $\mathrm{R}$ & $\mathrm{S}$ & $\mathrm{R}$ & $\mathrm{S}$ & $\mathrm{R}$ & $\mathrm{S}$ \\
\hline CIP $(5 \mu \mathrm{g})$ & $33 \%$ & & $2 \%$ & $98 \%$ & & $90 \%$ & $20 \%$ & $100 \%$ & $30 \%$ & $70 \%$ & ND & ND & & $100 \%$ \\
\hline $\mathrm{CPD}(30 \mu \mathrm{g})$ & $80 \%$ & $20 \%$ & $100 \%$ & $0 \%$ & $2 \%$ & $98 \%$ & $20 \%$ & $80 \%$ & $34 \%$ & $66 \%$ & ND & ND & $100 \%$ & $0 \%$ \\
\hline & $33 \%$ & & & & & & & & $80 \%$ & & $100 \%$ & $1 \%$ & & $0 \%$ \\
\hline PM $(30 \mu \mathrm{g})$ & $10 \%$ & $90 \%$ & $0 \%$ & $100 \%$ & $9 \%$ & $91 \%$ & $16 \%$ & $84 \%$ & $20 \%$ & $80 \%$ & ND & ND & $0 \%$ & $100 \%$ \\
\hline $\mathrm{N}(10 \mu \mathrm{g})$ & $73 \%$ & $27 \%$ & $60 \%$ & $40 \%$ & ND & ND & $80 \%$ & $20 \%$ & ND & ND & ND & ND & $0 \%$ & $100 \%$ \\
\hline & $45 \%$ & & & & $52 \%$ & $48 \%$ & & & $66 \%$ & $34 \%$ & ND & ND & & $0 \%$ \\
\hline $\mathrm{TE}(30 \mu \mathrm{g})$ & $20 \%$ & $80 \%$ & $18 \%$ & $82 \%$ & $1 \%$ & $99 \%$ & $20 \%$ & $80 \%$ & $20 \%$ & $80 \%$ & $30 \%$ & $70 \%$ & $100 \%$ & $0 \%$ \\
\hline PB $(30 \mu \mathrm{g})$ & $80 \%$ & $20 \%$ & ND & ND & ND & ND & $20 \%$ & $80 \%$ & ND & ND & ND & ND & $0 \%$ & $100 \%$ \\
\hline $\mathrm{NA}(30 \mu \mathrm{g})$ & $80 \%$ & $20 \%$ & $75 \%$ & $25 \%$ & $99 \%$ & $1 \%$ & $20 \%$ & $80 \%$ & $40 \%$ & $60 \%$ & ND & ND & $0 \%$ & $100 \%$ \\
\hline OFL $(5 \mu \mathrm{g})$ & $70 \%$ & $30 \%$ & ND & ND & ND & ND & ND & ND & ND & ND & $22 \%$ & $78 \%$ & $100 \%$ & $0 \%$ \\
\hline
\end{tabular}

$\mathrm{S}$ - susceptibility, $\mathrm{R}$ - resistance, $\mathrm{ND}$ - not done, (CIP - ciprofloxacin, CPD-cefpodoxime, AMO-amoxacilin, IMP-imipenum, N -Neomycin ,CHL-Chloramphenicol, PB-Polymyxin B, Na-Nalidixic acis, OFL-ofloxacin, TE-tetracycline) 
water and its presence is usually due to unhygienic handling, carriers, or polluted Halo tolerant fungi in salted and dried fish at coastal water (Chakrabarty and Varma, 1990). Dried fishes became contaminated when transferred to the retail market. Lack of proper packaging, insufficient drying and sanitary practices induces the rate of contamination (Paul et al., 2018). Sun -drying might reduce the microbial load in fish flesh but do not eliminate completely contaminants in most samples. In a similar, it was concluded that the poor quality of the sun-dried fishes may develop due to unhygienic processing, inadequate salting with poor quality salt and causality in case of packing of the fishes (Prakash, 2011).

\section{Conclusion}

Our present study revealed that both raw fish and sun -dried fish may nurture various pathogenic microorganisms. The microbial stability of dried fish products depends upon their moisture content. To control the flies, insects or pests, pesticide applied on the fish which is hazardous to the dry fish consumers, so fishermen should be aware of these things. Proper drying procedure is mandatory for achieving a high quality of dried fish. Very recently, the consumption of dry fish is not only popular to the Bangladeshi people but also getting its popularity to the people of Europe, the US and the Middle East. To improve the quality and ensure consumer acceptance it is obvious to run a training session for the dried fish processors and dried fish traders. In order to minimize the existence of drug resistant microflora in both the raw and dry fish, the fish processing company should have to be more careful about the cross contamination during the whole fish processing procedure. Government body should take necessary steps to improve the quality and safety of both raw and sun-dried fish produced in the coastal region of Bangladesh as well as to resist the frequent spreading of drug resistant microflora.

\section{References}

Acharjee, M., Ahmed, E., Munshi, S.K. and Noor, R. (2014). Validation of $\gamma$-irradiation in controlling microorganisms in fish. Nutrition and Food Science, 44(3), 258-266. https://doi.org/10.1108/NFS-072013-0089

Al-Sheraa, A.S. (2014). Microbial quality of three imported fresh locally produced marine fishes in AlFaw City, Basrah, Iraq. Journal of Aquaculture Research and Development, 9(4), 531. https:// doi.org/10.4172/2155-9546.1000531

Arannilewa, S.T., Salawu, S.O., Sorungbe, A.A. and Ola -Salawu, B.B. (2006). Effect of frozen period on the chemical, microbiological and sensory quality of frozen tilapia fish (Sarotherodun galiaenus). African Journal of Biotechnology, 18(2), 185-192. https:// doi.org/10.1177/026010600601800210

Atapattu, R. and Samarajeewa, U. (1990). Fungi associated with dried fish in Sri Lanka Mycopathologia, 111(1), 55-59. https:// doi.org/10.1007/bf02277304

Azam, K. (2002). Fisherman community of Kuakata, Bangladesh: Fisheries activities and quality of fish. Bangladesh: Khulna University

Balachandran, K.K. (2001). Post-Harvest Technology of Fish and Fish Products., p. 77. New Delhi, India: Daya Publishing House.

Bauer, A.W., Kirby, W.M.M., Sherris, J.C. and Tierch, M. (1966). Antibiotic susceptibility testing by a standardized single disc method. American Journal of Clinical Pathology, 45(4), 493-496. https:// doi.org/10.1093/ajcp/45.4_ts.493

Cappuccino, J.G. and Sherman, N. (1996). Microbiology - A Laboratory Manual. 4th ed. California: The Benjamin/Cummings Publishing Co., Inc.

Chakrabarti, R. and Varma, P.R.G. (1999). Halo Tolerant Fungi in Salted and Dried Fish Lower Visahapattinam Coast. Fishery Technology, 36, 2831.

Chowdhury, M.B.R. and Baqluis, M.A. (1997). Bacterial flora in formed carp (Labeorohita) in Bangladesh. In Flegel, T.W. and MacRae, I.H. (Eds). Diseases in Asian Aquaculture III: Proceedings of the Third Symposium on Disease in Asian Aquaculture Jan 29 - Feb 2, 1996, Bangkok, Thailand., p. 90-94. Manila: Fish Health Section, Asian Fisheries Society.

Das, M.F., Hafiz, M.K., Ahamed, M.K., Praveen, S. (2007). Microbiological analysis of some raw fish samples. Bangladesh Journal of Microbiology, 24 (1), 67-69. https://doi.org/10.3329/bjm.v24i1.1242

Dewi, R.S., Nurul, H. and Ahmad, R. (2011). Changes in the Physico-Chemical Properties, Microstructure and Sensory Characteristics of Shark Dendeng Using Different Drying Methods. American Journal of Food Technology, 6(2), 149-157. https:// doi.org/10.3923/ajft.2011.149.157

FAO. (1982). Reference manual to codes of practice for fish and fishery products. FAO Rome, Italy, pp: 152.

Felicia, S.C. and Jamila, P. (2003). Fungi in Salted Dried Fishes of Tuticorin, South East Coast of India, presented at the Proceeding of the Symposium on Seafood Safety: Status and Strategies, May 28-30, 2001. Cochin, India: Society of Fisheries Technologists (India) and CIFT.

Ferraro, M.J., Craig, W.A. and Dudley, M.N. (2001). 
Performance standards for antimicrobial susceptibility testing. $11^{\text {th }}$ ed. Pennsylvania, USA: NCCLS

Geetha, S., Sri Lakshmi, B., Karuna, Y., Rao, V.G., Krishna, N.M., Reddy, N.R.S., Bhavani, K. and Babu, K.R. (2014). Microbiological Examination of Three types of Common Edible Marine Fishes from Visakhapatnam Fishing Harbour, East Coast of India. World Journal of Fish and Marine Sciences, 6 (5), 471-474.

Gupta, R. and Samuvel, C.T. (1985). Aspergillus niger in dried fish Sample in Rainy Season in Cochin Coast. Fishery Technology, 22, 132.

Hasan, M.M., Shikha, F.H., Hossain, M.I., Kamal, M., Islam, M.N. and Wahab, M.A. (2006). Quality assessments of Traditional, Rotary and Solar Tunnel Dried Small Indigenous Fish Products. Bangladesh Journal of Fisheries Research, 10(1),73-84. https:// doi.org/10.20546/ijcmas.2016.509.044

Khan, M.A.A. and Khan, Y.S.A. (2001). Insects infestation and preventive measures in dry fish storage of Chittagong, Bangladesh. Journal of Biological Sciences, 1(10), 963-965. https://doi.org/ 10.3923/jbs.2001.963.965

Kim S.H., Barros-Velazquez, J., Ben-Gigirey, B., Eun, J.B., Jun, S.H, Wei, C. and An. H. (2003). Identification of the main bacteria contributing to histamine formation in seafood to ensure product safety. Food Science and Biotechnology, 12, 460

Munshi, S.K., Rahman, M.M. and Noor, R. (2012). Detection of virulence potential of diarrheagenic Escherichia coli isolated from surface water of rivers surrounding Dhaka City. Journal of Bangladesh Academy of Sciences, 36, 109-121. https:// doi.org/10.3329/jbas.v36i1.10927

Musa, U., Hati, S.S., Adamu, Y.I. and Mustapha, A. (2010). Pesticides Residues in Smoked Fish Samples from North-Eastern Nigeria. Journal of Applied Sciences, 10(11), 975-980. https://doi.org/ 10.3923/ jas.2010.975.980

Nowsad, A.K.M. (2003). New method of drying fish in solar fish dryer. Rome: Food and Agricultural Organization of the United Nations (Empowerment of coastal fishing community project).

Nur, I.T., Mou, A.N. and Habiba, U. (2020). Comparative microbiological analysis of four different sea fishes collected from the local market in Dhaka Metropolis. Food Research, 4(1), 161 - 165. https://doi.org/10.26656/fr.2017.4(1).253

Patterson, J. and Ranjitha, G. (2009). Qualities of commercially and Experimentally Sun-Dried Fin Fish Scomberoides tol. African Journal of Food
Science, 3(10), 299-302

Paul, P.R., Reza, M.S., Islam, M.N. and Kamal, M. (2018). A Review on Dried Fish Processing and Marketing in the Coastal Region of Bangladesh. Research in Agriculture Livestock and Fisheries, 5 (3), 381-390. https://doi.org/10.3329/ralf.v5i3.39587

Prakash, S. (2011). Microbial Quality of Salted and SunDried Sea Foods of Tuticorin Dry Fish Market, Southeast Coast of India. International Journal of Microbiological Research, 2(2), 188-195.

Ravichandran, S., Joseph, F.R.S, Kanagalakshmi, R. and Ramya M.S. (2012). Variation in Nutritive Composition of Two Commercially Important Marine Fin Fishes. International Journal of Zoological Research, 8(1), 43-51. https:// doi.org/10.3923/ijzr.2012.43.51

Saritha, K. and Patterson, J. (2012). Processing of Innovative Ready to Fry Crackers from Penaeus japonicas. World Journal of Dairy and Food Sciences, 7(1), 66-73

Saritha, K., Jayasantha, K.I., Aiyamperumal, V. and Patterson, J. (2012). Microbial and Biochemical Qualities of Salted and Sun-Dried Sea Foods of Cuddalore, Southeast Coast of India. International Journal of Microbiological Research, 3(2), 138-143

Shabeeb, S.S.A., Ibrahim, M.M.A. and Ramadhan, G.H.A. (2016). A Comparative Microbial Quality Assessment among Fishes, Prawns and Cuttlefishes collected from Dammam Fish Market. International Journal of Current Microbiology and Applied Sciences, 5(9), 405-418. https://doi.org/10.20546/ ijcmas.2016.509.044

Sharma, O.P. (1989). Textbook of Fungi., p. 365. New Delhi, India: Tata MC Graw-Hill publishing co. Ltd.

Yam, B.A.Z, Khomeiri, M., Amirkhani, S. and Sabagh, M. (2015). Microbial Quality of Salted Dried Fish Sold Near Caspian Sea, Iran. Open Research Journal of Fisheries and Aquaculture, 2(1), 1-8. 